\title{
Revista Colombiana de Ciencias Pecuarias
}

\section{Effects of genetic polymorphism in Pit1, GH, GHR and KCN3 on milk yield and body weight of Khuzestan (Iran) water buffaloes}

\author{
Efectos del polimorfismo genético en Pit1, GH, GHR y KCN3 sobre la producción de leche y el peso \\ corporal del búfalo de agua de Juzestán, Irán
}

\section{Efeitos do polimorfismo genético em Pit1, GH, GHR e KCN3 sobre produção de leite e peso corporal do búfalo de água do Cuzistão, Irã}
Meysam Ahmadzadeh ${ }^{1,2 \#}$, MSc; Farzad Rashidi ${ }^{1,2 \#}$, MSc; Hamed Amirpour Najafabadi ${ }^{3 \#}$, MSc.; Amir Jaferian ${ }^{4}, \mathrm{PhD}$; Shahin Eghbalsaied ${ }^{1,2,5^{*}}$, PhD.

\begin{abstract}
${ }^{1}$ Transgenesis Center of Excellence, Isfahan (Khorasgan) branch, Islamic Azad University, Isfahan, Iran.
${ }^{2}$ Department of Animal Science, Faculty of Agriculture, Isfahan (Khorasgan) branch, Islamic Azad University, Isfahan, Iran.

${ }^{3}$ Faculty of Agriculture and Life Sciences, Department of Agricultural Sciences, Lincoln University, Christchurch, New Zealand.

${ }^{4}$ Department of Animal Science, Ramin University of Agriculture and Natural Resources, Mollasani, Ahvaz, Khuzestan, Iran.

${ }^{5}$ Institute of Farm Animal Genetics, Friedrich-Loeffler-Institut (FLI), Mariensee, Neustadt am Rübenberge, Germany.
\end{abstract}

(Received: February 8, 2018; accepted: September 25, 2018)

doi: 10.17533/udea.rccp.v32n2a04

\begin{abstract}
Background: Genetic information is necessary to devise strategic plans aimed to improve the genetic merit of buffalos. Objective: To assess the effect of genetic polymorphisms in GH, Pit-1, GHR, GHRHR, and $\mathrm{KCN} 3$ genes on milk production and body weight of Khuzestan water buffaloes. Methods: Blood samples were collected from 60 buffaloes from the Khuzestan province, Iran. Using the PCR-RFLP technique, the amplified and digested fragments of GH/AluI, GHR/AluI, GHRHR/ HaeIII, Pit1/HinfI, and KCN3/HindIII were genotyped. Results: All animals were monomorphic for GHRHR. The frequency of mutant alleles for $\mathrm{GH}, \mathrm{GHR}, \mathrm{KCN} 3$, and Pit1 was 47.5, 74.2, 49.2, and 51.7\%, respectively. There were significant differences $(\mathrm{p}<0.0001)$ in the genotypic frequencies of GH, GHR, and Pit1 between high and low milk-yielding buffaloes.

\footnotetext{
a To cite this article: Ahmadzadeh M, Rashidi F, Najafabadi HÁ, Jaferian A, Eghbalsaied S. Effects of genetic polymorphism in Pit1, GH, GHR and KCN3 on milk yield and body weight of Khuzestan (Iran) water buffaloes. Rev Colomb Cienc Pecu 2019; 32(2):107-116.

* Corresponding author: Shahin Eghbalsaied. Transgenesis Center of Excellence, Isfahan (Khorasgan) branch, Islamic Azad University, P.O. box 81595-158, Isfahan, Iran. E-mail address: shahin.eghbal@khuisf.ac.ir

\# These authors contributed equally to this work.
} 
The GH $(\mathrm{p}=0.0002)$, GHR $(\mathrm{p}<0.0001)$ and Pit1 $(\mathrm{p}<0.0001)$ polymorphisms also had significant effects on body weight. Sequencing results revealed the presence of C496A, G495A, G498A and C1501T SNPs in the GH, and G1702T in the GHR gene of Khuzestan buffalos. Conclusion: This study highlights the importance of GH, GHR, and Pitl on milk production and body weight of Khuzestan buffaloes. The results suggest that devising an integrated breeding plan in Khuzestan water buffalos can considerably benefit from the very high diversity in candidate genes.

Keywords: animal breeding, casein, genetic variation, growth hormone, milk production, SNP.

\section{Resumen}

Antecedentes: La información genética es necesaria para diseñar planes estratégicos con el objeto de mejorar el mérito genético de los búfalos. Objetivo: Evaluar el efecto de los polimorfismos genéticos en los genes GH, Pit-1, GHR, GHRHR y KCN3 sobre la producción láctea y peso corporal de búfalos de agua de la provincia de Juzestán, Iran. Métodos: Se recolectaron 60 muestras de sangre de búfalos de la provincia de Juzestán, en Irán. Los fragmentos amplificados y digeridos de GH/AluI, GHR/AluI, GHRHR/HaeIII, Pit1/HinfI y KCN3/HindIII fueron clasificados genotípicamente, utilizando la técnica PCR-RFLP. Resultados: Todos los animales fueron monomórficos para el gen GHRHR. La frecuencia alélica de alelos mutantes para los genes GH, GHR, KCN3 y Pit1 fue 47,5, 74,2, 49,2 y $51,7 \%$, respectivamente. Se encontraron diferencias significativas $(\mathrm{p}<0,0001)$ en las frecuencias genotípicas de $\mathrm{GH}$, GHR y Pitl entre búfalos de alta y baja producción. El efecto del polimorfismo $\mathrm{GH}$ ( $\mathrm{p}=0,0002), \mathrm{GHR}(\mathrm{p}<0,0001)$ y Pit1 $(\mathrm{p}<0,0001)$ también fue significativo para peso corporal. Los resultados de la secuenciación revelaron la presencia de SNPs C496A, G495A, G498A y C1501T en GH, y G1702T en el gen GHR. Conclusiones: Este estudio resalta la importancia de los genes GH, GHR y Pit1 sobre la producción de leche y el peso corporal de búfalos de Juzestán. Los resultados sugieren que la elaboración de un plan de cruzamiento integrado en búfalos de agua de Juzestán puede beneficiarse considerablemente de la gran diversidad de genes candidatos.

Palabras clave: caseina, hormona del crecimiento, producción de leche, reproducción animal, SNP, variación genética.

\section{Resumo}

Antecedentes: Determinação informações genéticas é o passo crítico para elaborar planos estratégicos com o objetivo de melhorar o mérito genético dos búfalos. Objetivo: Avaliar o efeito de polimorfismos genéticos nos genes GH, Pit-1, GHR, GHRHR e KCN3 na produção de leite e no peso corporal dos búfalos de água do Cuzistão, Irã. Métodos: Amostras de sangue foram coletadas de 60 búfalos da província de Cuzistão, no Irã. Utilizando a técnica PCR-RFLP, os fragmentos amplificados e digeridos de GH/AluI, GHR/AluI, GHRHR/HaeIII, Pit1/HinfI e KCN3/ HindIII foram genotipados. Resultados: Todos os animais eram monomórficos para o gene GHRHR. A freqüência alélica de alelos mutantes para os genes GH, GHR, KCN3 e Pit1 foi 47,5, 74,2, 49,2 e 51,7\%, respectivamente. Uma diferença significativa $(\mathrm{p}<0,0001)$ foi encontrada nas freqüências genotípicas de os genes $\mathrm{GH}$, GHR e Pit1 entre búfalos de alta e baixa produção. O efeito do polimorfismo GH ( $p=0,0002), G H R(p<0,0001)$ e Pit1 $(p<0,0001)$ também foi significativo para o peso corporal. Os resultados da sequenciação revelaram a presença de SNPs C496A, G495A, G498A e C1501T no GH, e G1702T no gene GHR dos buffalos do Cuzistão. Conclusões: Este estudo destacou a importância da GH, GHR e Pit1 na produção de leite e no peso corporal de buffalos do Cuzistão. Os resultados sugerem que a elaboração de um plano de melhoramiento genético integrado em búfalos de água do Cuzistão pode beneficiar consideravelmente da grande diversidade de genes candidatos.

Palavras-chave: caseína, hormônio do crescimento, produção de leite, reprodução animal, SNP, variação genética.

\section{Introduction}

Based on archeological evidence, water buffaloes were domesticated in Iran from 2500 BC (Naserian and Saremi, 2007). Buffaloes adaptability to low quality grasses, high temperature and humidity, irregular rainfall, disease resistance along with having a long productive life made them the first option as domestic animals for providing milk and meat in Iran (Dezfuli et al., 2011). In comparison to cow milk, Khuzestan buffalo milk has more fat $(6.6 \%)$ and solid content (Borghese and Mazzi, 2005). This prominent benefit of Khuzestan buffalo can compensate for the low fat percentage of Iranian Holstein dairy cows 
(Eghbalsaied et al., 2016), and is the subject of growing attention in the Iranian dairy market.

Several studies have been conducted to identify the major genes responsible for milk production and composition in dairy cows (Komisarek and Dorynek, 2009; Pasandideh et al., 2015). The polymorphism in growth hormone $(\mathrm{GH})$ was associated with selection for milk fat production in Red Danish and Norwegian Red cattle (Høj et al., 1993). It controls energy metabolism in high-yield cows (Hart et al., 1978), affects the size of mammary tissue (Capuco and Akers, 2009), reduces the apoptosis rate of the mammary cells (Accorsi et al., 2002), and consequently increases milk production (Yao et al., 1996). The growth hormone receptor (GHR) can also affect milk and fat yield of dairy cows (Jiang and Lucy, 2001; Viitala et al., 2006). Growth hormonereleasing hormone receptor (GHRHR) is secreted by the hypothalamus and stimulates the release of pituitary growth hormones (Godfrey et al., 1993). Besides these genes, a number of miscellaneous genes are involved in milk yield and milk contents. Among them, pituitary-specific transcription factor-1 (Pit1), also known as POU domain-class 1 transcription factor 1 (POU1F1) and Kappa-Casein (KCN3) are important genes involved in milk quality (Erwin et al., 1983; Fries et al., 1993; Lien and Rogne, 1993).

Although the importance of the above-mentioned genes has been well documented in dairy cows, there are limited publications on their role in buffaloes. Therefore, providing the genetic polymorphism of these candidate genes is essential for devising an integrated breeding plan for water buffalos. The goal of the present study was to assess the effect of genetic polymorphisms in GH, Pit-1, GHR, GHRHR, and $\mathrm{KCN} 3$ genes on milk production and body weight of water buffaloes in Khuzestan province, Iran.

\section{Material and methods}

\section{Ethical considerations}

The method for blood sampling was approved by the Animal Care and Ethics Committee of Isfahan Islamic Azad University, April 2014 (Nr. 15021393).

\section{Animals and location}

Blood samples were collected from 60 buffaloes from the Ahvaz $\left(31^{\circ} 19^{\prime} 13^{\prime \prime} \mathrm{N} 48^{\circ} 40^{\prime} 09^{\prime \prime} \mathrm{E}\right)$ and Dezful $\left(32^{\circ} 22^{\prime} 57^{\prime \prime} \mathrm{N} 48^{\circ} 24^{\prime} 07^{\prime \prime} \mathrm{E}\right)$ districts in the Khuzestan province, Iran. The buffaloes were 4 to 15 years old. Based on twice daily milking, animals were divided into low-yielding $(<10 \mathrm{~kg})$ and highyielding $(>13 \mathrm{~kg})$ dairy buffaloes. In addition, based on their body weight, buffaloes were classified into three categories: light $(<450 \mathrm{~kg})$, moderate $(450-500 \mathrm{~kg})$, and heavy $(>550 \mathrm{~kg})$. Breeding and feeding conditions were similar in the rural riverine production for all animals.

DNA was extracted from blood samples using a SinaClon kit, and polymerase chain reaction (PCR) was carried out for amplification of $\mathrm{GH}$, GHR, GHRHR, Pit1, and KCN3 genes using the specific primer sequences (Table 1) (Moody et al., 1995; Woollard et al., 1994); (Andreas et al., 2010); (Balogh et al., 2009); (Kalashnikova et al., 2009). Amplification of segments of interest (Table 1) was performed in $20 \mu 1$ reaction volume containing $100 \mathrm{ng}$ of genomic DNA, $5 \mu \mathrm{M}$ of each primer pairs, $0.2 \mathrm{mM}$ dNTPs, 10X PCR buffer, $2 \mathrm{mM} \mathrm{MgCl}$, and 1.5 units of Taq DNA polymerase (SinaClon, Iran). The PCR program for amplification of the desired targets was as follows: an initial denaturation at $94{ }^{\circ} \mathrm{C}$ for 4 minutes, 35 cycles comprising $94{ }^{\circ} \mathrm{C}$ for 50 seconds, 62, 53, and $53{ }^{\circ} \mathrm{C}$ (for $\mathrm{GH}, \mathrm{GHR}$, and GHRHR, respectively) for 50 seconds, and 72 ${ }^{\circ} \mathrm{C}$ for 50 seconds, followed by a final extension at $72{ }^{\circ} \mathrm{C}$ for 7 minutes. Then, the PCR product of GH and GHR genes underwent digestion with AluI, while GHRHR amplicon was digested with HaeIII restriction enzyme (Maga et al., 2006). In addition, Pit1 and KCN3 amplicons were digested with HinfI and HindIII, respectively. Samples were genotyped using the restriction fragment length polymorphism (RFLP) assay (Table 1). Briefly, $10 \mu$ of the PCR product was incubated with $2 \mathrm{IU}$ of the corresponding restriction enzyme at $37^{\circ} \mathrm{C}$ for two hours. The digested products were electrophoresed on a $2 \%$ agarose gel. In addition, the PCR products of GH and GHR from a random sample of animals were sequenced. 
Table 1. Primers used for PCR-RFLP (restriction fragment length polymorphism) on candidate genes for milk and meat production in Khuzestan water buffalo.

\begin{tabular}{|c|c|c|c|c|c|}
\hline Gene & Gene ID & Sequence of Primer & $\begin{array}{l}\text { Amplicon } \\
\text { length (bp) }\end{array}$ & $\begin{array}{l}\text { Restriction } \\
\text { site }\end{array}$ & Reference \\
\hline $\mathrm{GH}$ & NW_005781989 & $\begin{array}{l}\text { F:CGGACCGTGTCTATGAGAAGCTGAAG } \\
\text { R:GTTCTTGAGCAGCGCGTCGTCA }\end{array}$ & 432 & Alul & (Balogh et al., 2009) \\
\hline GHR & NW_005785241 & $\begin{array}{l}\text { F:GCTTACTTCTGCGAGGTAGACGC } \\
\text { R:GTCTGTGCTCACATAGCCAC }\end{array}$ & 298 & Alul & (Andreas et al., 2010) \\
\hline GHRHR & NW_005782772 & $\begin{array}{l}\text { F:GTAAGGATGCCAGCTCTGGGT } \\
\text { R:TGCCTGCTCATGATGTCCTGGA }\end{array}$ & 451 & Haelll & (Moody et al., 1995) \\
\hline KCN3 & NW_005785429 & $\begin{array}{l}\text { F:ATAGCCAAATATATCCCAATTCAGT } \\
\text { R:TTTATTAATAAGTCCATGAATCTTG }\end{array}$ & 531 & HindIII & (Kalashnikova et al., 2009) \\
\hline Pit1 & NW_005785338 & $\begin{array}{l}\text { F:AAACCATCATCTCCСTTCTT } \\
\text { R:AATGTACAATGTGCCTTCTGAG }\end{array}$ & 435 & Hinfl & (Woollard et al., 1994) \\
\hline
\end{tabular}

\section{Statistical analysis}

Genotypic and allelic frequencies were estimated using the PopGene software, Version 1.31 (Yeh et al., 1999). Genotypic and allelic frequencies were compared between classes of milk yield and body weight using a Chi-square test. A p-value $<0.05$ was considered significant.

\section{Results}

The effect of polymorphisms using PCR-RFLP on milk yield and body weight
Using the RFLP technique, genetic polymorphism was assessed in five candidate genes in relation to milk yield of Iranian water buffalo. Using the HaeIII restriction enzyme, the previously detected mutation in GHRHR (Maga et al., 2006) was not detected in the Iranian water buffaloes. Implementation of the restriction enzymes for GH, GHR, Pit1, and KCN3 resulted in detection of polymorphisms, corresponding to other studies on water buffalo around the world. Allelic frequencies of GH, GHR, Pit1, and KCN3 genes are presented in Table 2. The allelic frequencies of mutant alleles for GH/AluI, GHR/AluI, KCN3/ HindIII, and Pit1/HinfI were 47.5, 74.2, 49.2, and $51.7 \%$, respectively.

Table 2. Allelic and genotypic frequencies of GH/Alul, GHR/Alul, KCN3/HindIII, and Pit1/Hinfl in Khuzestan water buffaloes.

\begin{tabular}{lccccc}
\hline \multirow{2}{*}{ Gene/Restriction enzyme } & \multicolumn{3}{c}{ Genotype frequency (\%) } & \multicolumn{2}{c}{ Allelic frequency (\%) } \\
\cline { 2 - 6 } & $\mathbf{+ / +}$ & $\mathbf{+ / M}$ & $\mathbf{M} / \mathbf{M}$ & $\mathbf{+}$ & $\mathbf{M}$ \\
\hline GH/Alul & 5.0 & 75.0 & 20.0 & 42.5 & 47.5 \\
GHR/Alul & 6.7 & 38.3 & 55.0 & 25.8 & 74.2 \\
KCN3/HindIII & 8.3 & 85.0 & 6.7 & 50.8 & 49.2 \\
Pit1/Hinfl & 33.3 & 30.0 & 36.7 & 48.3 & 51.7 \\
\hline
\end{tabular}

There was a significant difference in GH/AluI genotypic frequency between high and low milk-yielding buffalos $(\mathrm{p}<0.0001)$. Frequency of the wild type allele was higher in the low-yielding group, while the mutant allele was more abundant in the high-yielding group (Figure 1). 


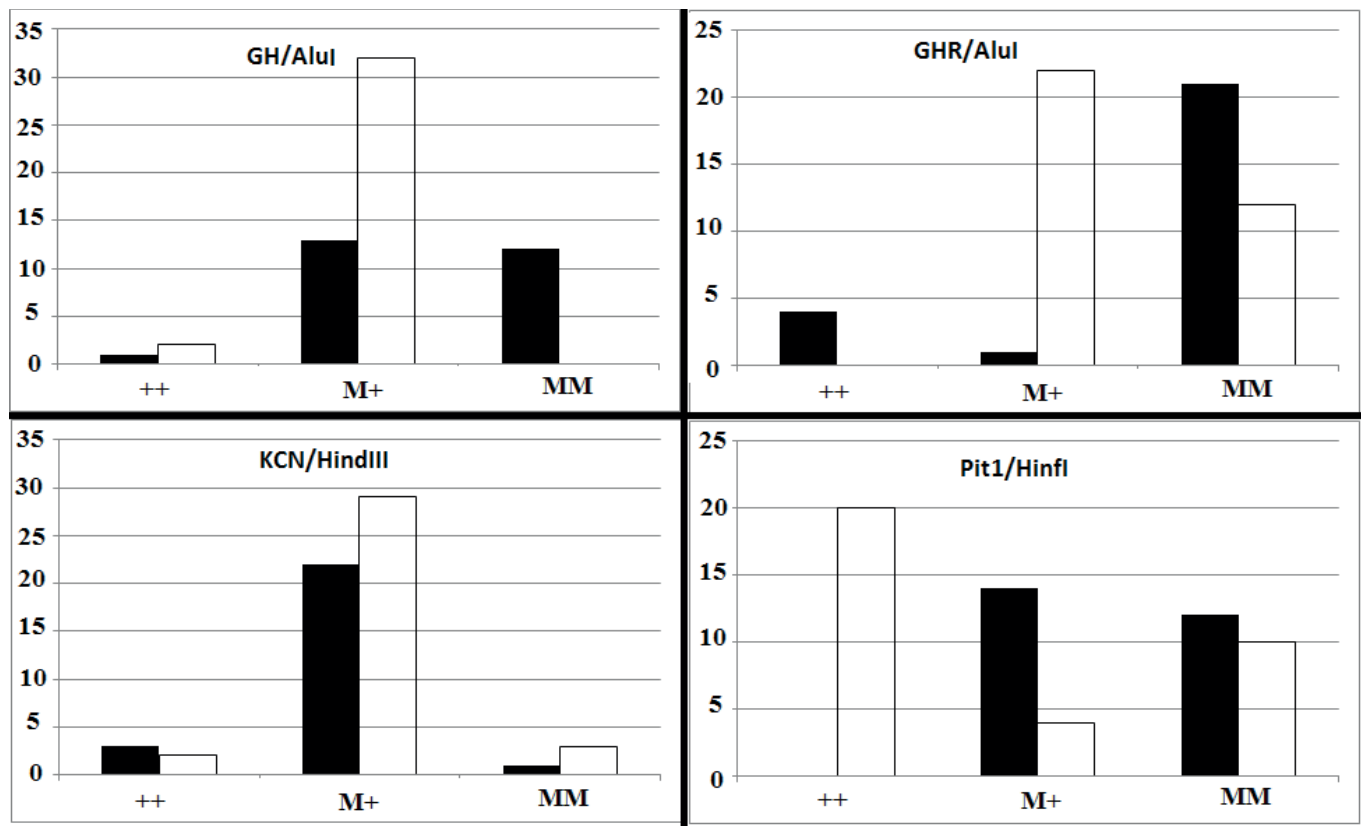

Figure 1. Genotypic distribution of GH/AluI ( $<<0.0001$ ), GHR/AluI, KCN3/HindIII ( $\mathrm{p}=0.5729$ ), and Pit1/HinfI ( $<<0.0001)$ in two classes of high- (black bar) and low-yielding (white bar) Khuzestan water buffalo. M and + indicate mutant and wild type alleles, respectively.

Also, there was a significant difference in genotypic frequency of GH between body weight classes $(\mathrm{p}=0.0002)$ (Figure 2).
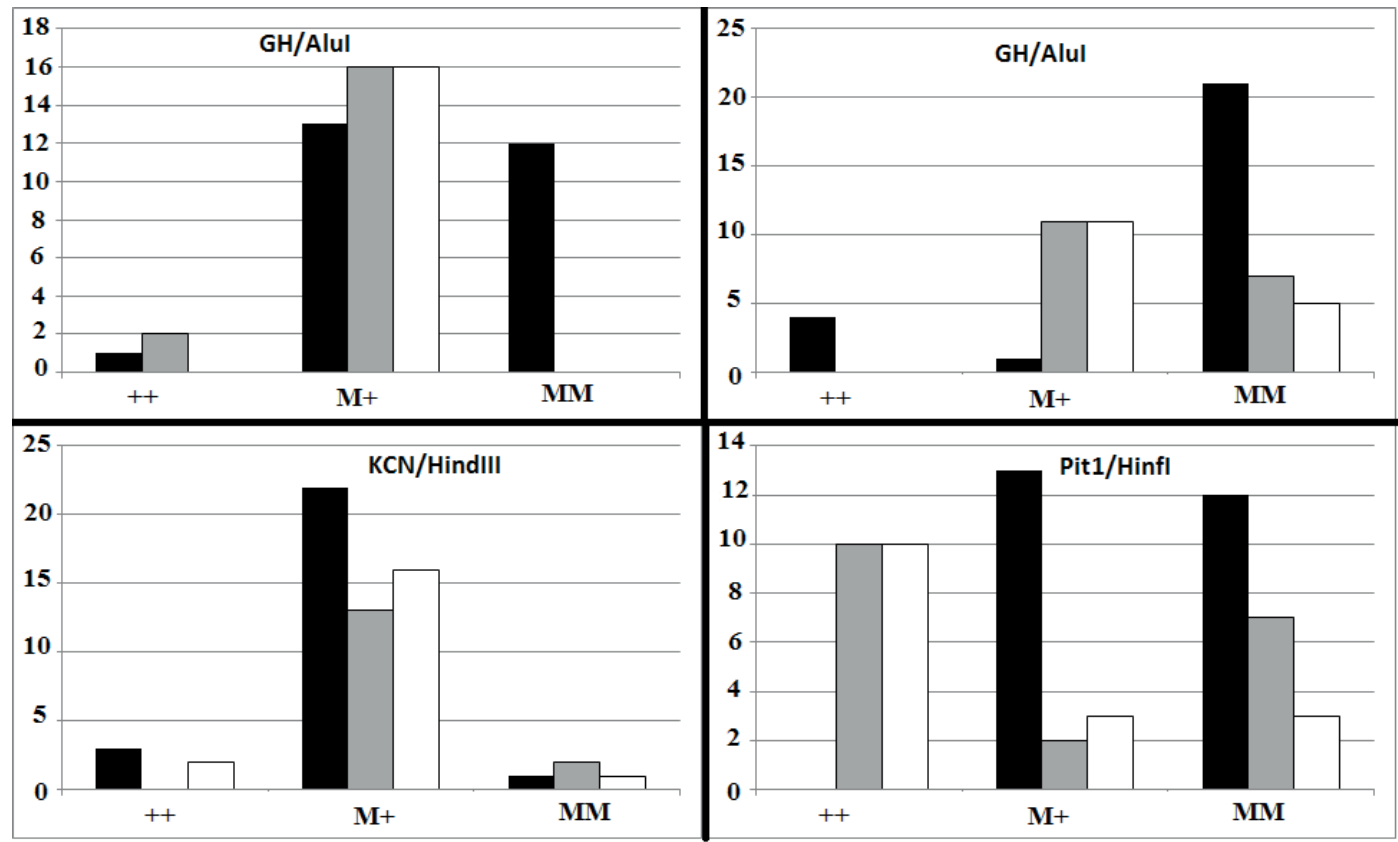

Figure 2. Genotypic distribution of GH/AluI ( $\mathrm{p}=0.0002)$, GHR/AluI $(\mathrm{p}<0.0001)$, KCN3/HindIII ( $\mathrm{p}=0.5489$ ), and Pit1/HinfI $(\mathrm{p}<0.0001)$ in three classes of light- (black bar), moderate- (gray bar), and heavy-weight (white bar) Khuzestan water buffalo. $\mathrm{M}$ and + indicate mutant and wild-type alleles, respectively. 
The effect of the GHR allele detected by the AluI restriction enzyme was also significantly different between high and low milk-yielding groups $(p<0.0001)$. Although the majority of high-yielding buffaloes were homozygote for MM, all of the lowyielding buffaloes carried at least one mutant allele for the GHR/AluI restriction site. There was a significant difference in distribution of genotypic frequencies of GHR/AluI between body weight classes $(\mathrm{p}<0.0001)$. The majority $(84.0 \%)$ of heavy-weight buffalos were homozygote mutant for GHR/AluI.

No significant difference was observed for $\mathrm{KCN} 3$ allelic and genotypic frequencies among either milk production or body weight classes. The effect of detected Pit1 polymorphism on milk production was statistically significant $(\mathrm{p}<0.0001)$. Fifty-eight percent of low-yielding buffalos were PP homozygous, while no animals from the high-yielding group were homozygous PP. In addition, Pit1/HinfI genotypic frequencies were significantly different among body weight groups $(\mathrm{p}<0.0001)$.

Sequencing results of $G H$ and $G H R$ revealed multiple SNPs in Iranian water buffalo

Results of sequencing revealed four mutations in $\mathrm{GH}$ and one mutation in GHR genes of Iranian water buffalos, compared to the NCBI reference sequences of NM_001290929.1 and NM_001290971.1, respectively (Figure 3). The mutations in DNA of GH correspond to G495A, C496A, and G498A conversions in the mRNA sequence. One of these mutations, C496A, was a missense mutation, which causes Q166K (Glutamine to Lysine) (Figure 3). Both the G495A and G498A were silent mutations for Lys (Lysine) and Thr (Threonine). In addition, one mutation was detected in intronic region 4 , $\mathrm{C} 1501 \mathrm{~T}$ of $\mathrm{GH}$. The only detected mutation in the GHR gene corresponded to the G1702T mutation in mRNA sequence, which was a silent mutation for Ile (Isoleucine) at position 561 .

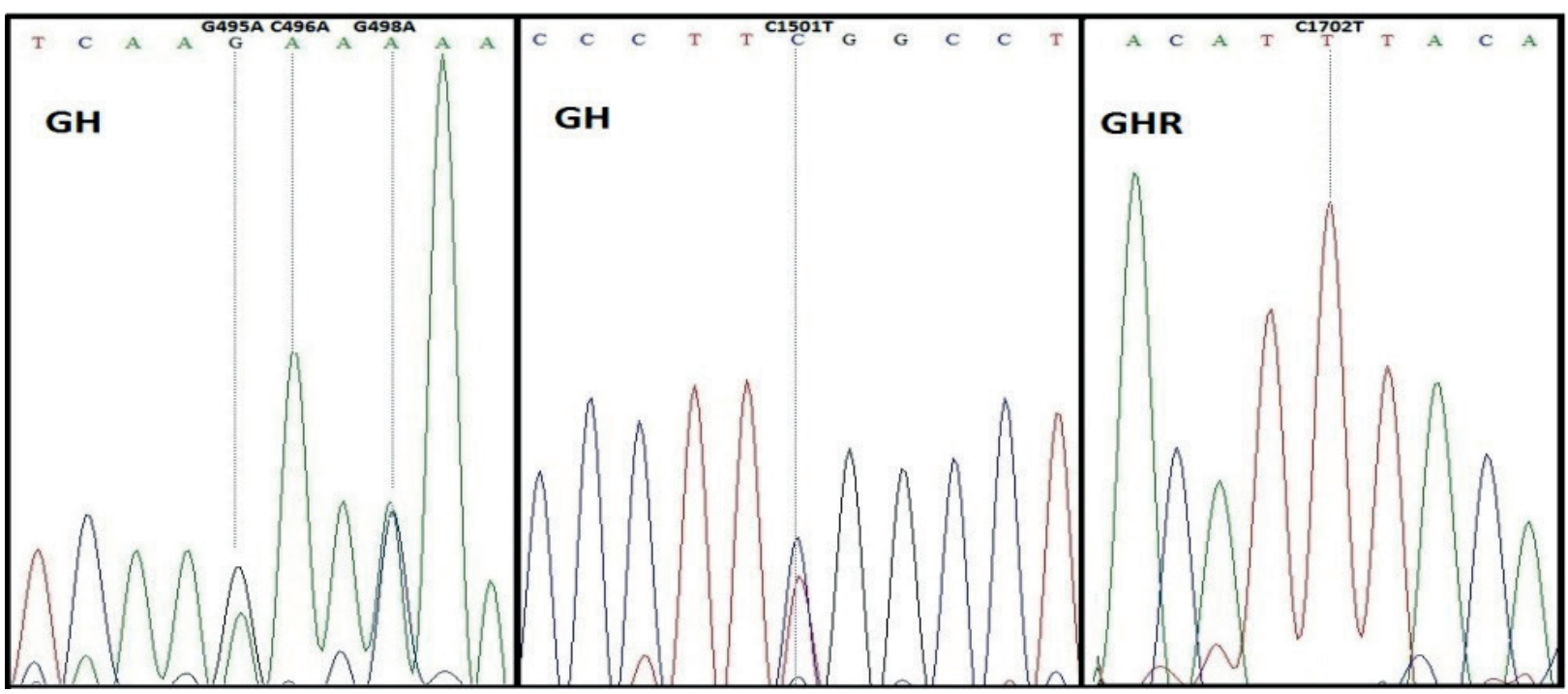

Figure 3. Presence of SNPs in GH and GHR of Iranian Khuzestan water buffalo.

\section{Discussion}

Khuzestan buffalos are distributed in the tropical zone of Iran and Iraq with a population of more than 104,000 and 120,000 water buffaloes, respectively (Borghese, 2010). An average annual population growth of $2.6 \%$ has been reported in Iranian Khuzestan buffalos (Kamalzadeh et al., 2008). Defining important genes responsible for growth rate and milk yield is critical to uncover the genetic mechanism controlling these attributes in water buffalo. However, documentation is limited on the importance of these genes in water buffalo while several studies have documented the importance of growth factors on the 
performance of dairy cows (Bauman et al., 2015; Berry et al., 2016; Bines and Hart, 1982; Hadi et al., 2015; Machlin, 1973). Therefore, defining candidate genes that can play key roles in milk and meat production is an essential step for the genetic improvement of water buffaloes. Subsequently, identifying missense and nonsense mutations in the candidate genes can be helpful in animal genetic/genomic selection. In this study, polymorphisms in GH, GHR and GHRH as well as KCN3 and Pit1 genes in Khuzestan buffalo were investigated. The results indicated that except for GHRH, all the assessed genes using the RFLP technique were polymorphic. The mutant alleles were highly abundant in the studied population, ranging from 47.5 to $74.2 \%$ in GH and GHR, respectively. This result confirmed the findings of previous studies indicating the presence of high genetic diversity in Iranian buffalo and water buffalo (Heydarian et al., 2014; Javanmard et al., 2005; Ranjbar et al., 2016; Shokrollahi et al., 2009; Taghizadeh et al., 2014). The results of PCR-RFLP for GH/AluI and GHR/AluI genes showed that the frequency of mutant allele was $3.5 \%$ in Iraqi water buffaloes, while all animals were monomorphic for the GHR/AluI allele. No polymorphism was detected using the RFLP method for GH and GHR genes in Egyptian water buffaloes (Hussain, 2015). A study of Bangladesh water buffalos for GHRHR showed the presence of both mutant and wild type alleles (Andreas et al., 2010). All animals in the present study were monomorphic wild type for GHRHR. Our results showed that both Pit1 and KCN3 are highly polymorphic in Khuzestan buffaloes. Although the Pit1/Hinfl mutation was characterized in Indian and Indonesian buffaloes (Jakaria and Noor, 2015; Parikh and Rank, 2013). Assessment of this mutation in Egyptian buffaloes showed a lack of polymorphism (Nasr et al., 2016). Moreover, KCN3/ HindIII was wild type monomorphic in Pakistani buffalo (Riaz et al., 2015). Our results indicate that local buffaloes can be substantially variable for the assessed genes. Iranian Khuzestan water buffaloes have some similarity with Iraqi Khuzestan buffaloes and may have originated from the same ancestor (Watanabe et al., 1994). However, the results of the present study showed that, unlike Iraqi water buffaloes, Iranian water buffaloes are polymorphic for GHR/AluI. Recently released data indicated the presence of high genetic diversity of African buffalo in nine African countries (Smitz et al., 2016)the African buffalo (Syncerus caffer. Therefore, the present study highlighted the importance of sequencing candidate genes in buffaloes from each specific local area to devise a proper strategy for genetic selection.

A single mutation in the Pit1 gene causes a substantial deficiency in anterior pituitary Pit-1 hormone production and subsequently an aberrant activation of $\mathrm{GH}$ and prolactin genes (Cohen et al., 1996). A polymorphism in Pit1 gene was associated with milk traits in Egyptian and Indian buffaloes (Othman et al., 2011; Parikh and Rank, 2013). In addition, water buffaloes carry polymorphism in the KCN gene (Cinar et al., 2015; Mitra et al., 1998), which can affect their milk yield as well as feta cheese processing parameters (Shakerian et al., 2016).

We then looked at whether the detected polymorphism was associated with milk production and body weight traits. The results indicated that the majority of buffaloes from the high-yielding group carried the mutant allele for GH, GHR, and Pit1. Moreover, the genotypic distribution of GHR and Pit1 was different between body weight classes, so that the mutant alleles were more abundant in buffaloes from the heavy weight class. The effect of $\mathrm{GH}$ as a metabolic modifier in livestock has been well documented (Dunshea et al., 2016). An association of Pit1 with milk yield in buffalo was suggested by Parikh and Rank (2013). In line with our results, a recent study on Egyptian water buffalo verified the importance of Pit1 polymorphism on milk yield and body weight (Nasr et al., 2016). Therefore, our results indicate that besides employing growth hormones on dairy farms, there is a high potential for genetically selecting and upgrading $\mathrm{GH}$ and Pit1 as growth factors as well GHR in dairy buffaloes. However, KCN3 polymorphism was not associated with either milk yield or body weight traits. This indicates that the mutation has not been under selection pressure either naturally or artificially for milk and meat production in Iranian water buffalo.

Finally, the PCR amplicons from GH and GHR were sequenced to see if further mutations exist in these genes. Our results showed the presence of several mutations in GH and one mutation in GHR. Among them, the C496A causes Q166K (Glutamine to Lysine) in GH polypeptide. None of these 
mutations have been reported in the literature. The detected mutation in GHR has not been reported in the literature and is different from the detected mutation by Shi et al. (2012). Therefore, to the best of our knowledge, no literature has been published on the association of detected mutations and milk/meat attributes of buffalo. Nonetheless, an association study with a larger sample size is yet to be explored if the detected SNPs in the present study are associated with production performance of water buffalo.

In conclusion, our results suggest that a high number of SNPs may segregate in GH and GHR genes of Iranian buffalo. It should be noted that the majority of polymorphism studies, including this study, have been based on the PCR-RFLP results from bovine genome. Results of this study provides information for one missense mutation in $\mathrm{GH}$ and highlighted that sequencing the candidate genes in buffaloes can be very practical to survey the prevalence and importance of possible SNPs in buffalos. These data can provide information about genetic diversity as well as association analysis of the above-mentioned genes for further application in selection programs of Khuzestan buffaloes.

\section{Acknowledgements}

This project was carried out at the Transgenesis Center of Excellence, Isfahan (Khorasgan) branch, Islamic Azad University, Isfahan, Iran. Shahin Eghbalsaied was supported by the Alexander von Humboldt Foundation under grant number: Ref 3.4 IRN - 1191261 - GF-E.

\section{Conflicts of Interest}

Authors declare they have no conflicts of interest with regard to the work presented in this report.

\section{References}

Accorsi P, Pacioni B, Pezzi C, Forni M, Flint D, Seren E. Role of prolactin, growth hormone and insulin-like growth factor 1 in mammary gland involution in the dairy cow. J Dairy Sci 2002; 85(3):507-13.
Andreas E, Sumantri C, Nuraini H, Farajallah A, Anggraeni A. Identification of $\mathrm{GH} \mid \mathrm{AluI}$ and GHR $\mid$ AluI genes polymorphisms in Indonesian Buffalo. J Indonesian Trop Anim Agric 2010; 35(4):215-21.

Balogh O, Kovács K, Kulcsár M, Gáspárdy A, Fébel H, Zsolnai A, Fésüs L, Delavaud C, Chilliard Y, Gilbert R. Interrelationship of growth hormone AluI polymorphism and hyperketonemia with plasma hormones and metabolites in the beginning of lactation in dairy cows. Livest Sci 2009; 123(2):180-6.

Bauman D, St-Pierre N, Milliken G, Collier R, Hogan J, Shearer J, Smith K, Thatcher W, Eastridge M. An updated meta-analysis of bovine somatotropin: effects on health and welfare of dairy cows. 24th Tri-State Dairy Nutrition Conference, Fort Wayne, Indiana, USA, 20-22 April, 2015: The Ohio State University.

Berry D, Friggens N, Lucy M, Roche J. Milk production and fertility in cattle. Annu rev anim biosci 2016; 4:269-90.

Bines J, Hart I. Metabolic limits to milk production, especially roles of growth hormone and insulin. J Dairy Sci 1982; 65(8):1375-89.

Borghese A, Mazzi M. Buffalo population and strategies in the world. Buffalo production and research 2005; 67:1-39.

Borghese A. Development and perspective of buffalo and buffalo market in Europe and Near East, Proceedings of the 9th World Buffalo Congress; 2010 25-28 April, Buenos Aires, Argentina.

Capuco AV, Akers RM. Management and environmental influences on mammary gland development and milk production. Managing the prenatal environment to enhance livestock productivity: Springer; 2009. p. 259-92.

Cinar MU, Akyuz B, Arslan K, Ilgar EG. Genotyping of the kappa-casein and beta-lactoglobulin genes in Anatolian water buffalo by PCR-RFLP. Int J Dairy Technol 2015; 69:308-311

Cohen LE, Wondisford FE, Radovick S. Role of Pit-1 in the gene expression of growth hormone, prolactin, and thyrotropin. Endocrinol Metab Clin North Am 1996; 25(3):523-40.

Dezfuli BT, Javaremi AN, Abbasi M, Fayazi J, Chamani M. Economic weights of milk production traits for buffalo herds in the southwest of Iran using profit equation. World Applied Sciences Journal 2011; 15(11):1604-13.

Dunshea F, D'Souza D, Channon H. Metabolic modifiers as performance-enhancing technologies for livestock production. Animal Frontiers 2016; 6(4):6-14.

Eghbalsaied S, Akasheh L, Honarvar M, Forouzandeh AD, Ghazikhani-Shad A, Bankizadeh F, Abdullahpour R. Fine-tuning of season definition for genetic analysis of fertility, productivity, and longevity traits in Iranian Holstein dairy cows. Kuwait J Sci Eng 2016; 43(1).

Erwin CR, Croyle ML, Donelson JE, Maurer RA. Nucleotide sequence of cloned complementary deoxyribonucleic acid for 
the. alpha. subunit of bovine pituitary glycoprotein hormones. Biochemistry-US 1983; 22(20):4856-60.

Fries R, Eggen A, Womack JE. The bovine genome map. Mamm Genome 1993; 4(8):405-28.

Godfrey P, Rahal JO, Beamer WG, Copeland NG, Jenkins NA, Mayo KE. GHRH receptor of little mice contains a missense mutation in the extracellular domain that disrupts receptor function. Nat Genet 1993;4(3):227-32.

Hadi Z, Atashi H, Dadpasand M, Derakhshandeh A, Seno MG. The relationship between growth hormone polymorphism and growth hormone receptor genes with milk yield and reproductive performance in Holstein dairy cows. Iran J Vet Res 2015; 16(3):244.

Hart IC, Bines JA, Morant S, Ridley J. Endocrine control of energy metabolism in the cow: comparison of the levels of hormones (prolactin, growth hormone, insulin and thyroxine) and metabolites in the plasma of high-and low-yielding cattle at various stages of lactation. J Endocrinol 1978; 77(3):333-45.

Heydarian D, Miraei-Ashtiani SR, Sadeghi M. Study on DGAT1-exon8 Polymorphism in Iranian Buffalo. International Journal of Advanced Biological and Biomedical Research 2014; 2(7):2276-82.

Høj S, Fredholm M, Larsen N, Nielsen VH. Growth hormone gene polymorphism associated with selection for milk fat production in lines of cattle. Anim Genet 1993; 24(2):91-6.

Hussain D. Molecular Characterization of Some Productivity Triats in Mesopotamian Buffaloes (Bubalus bubalis). Eur J Mol Biotechnol 2015; 8(2):80-7.

Jakaria J, Noor RR. Identification of a Single Nucleotide Polymorphism at Hinf-1 Enzyme Restriction Site of Pit-1 Gene on Indonesian Bali Cattle Population. Trop Anim Sci J 2015; 38(2):104-9.

Javanmard A, Asadzadeh N, Banabazi MH, Tavakolian J. The allele and genotype frequencies of bovine pituitary specific transcription factor and leptin genes in Iranian cattle and buffalo populations using PCR-RFLP. Iran J Biotechnol 2005; 3:104-8.

Jiang H, Lucy MC. Variants of the 5'-untranslated region of the bovine growth hormone receptor mRNA: isolation, expression and effects on translational efficiency. Gene 2001; 265(1):45-53.

Kalashnikova L, Khabibrakhmanova YA, Tinaev AS. Effect of polymorphism of milk protein and hormone genes on milk productivity of black pied cows. Russ Agric Sci 2009; 35(3):192-5.

Kamalzadeh A, Rajabbaigy M, Kiasat A. Livestock production systems and trends in livestock industry in Iran. J Agri Soc Sci 2008; 4:183-88.

Komisarek J, Dorynek Z. Effect ofABCG2, PPARGC1A, OLR1 andSCD1 gene polymorphism on estimated breeding values for functional and production traits in Polish Holstein-Friesian bulls. $\mathrm{J}$ appl genet 2009; 50(2):125-32.

Lien S, Rogne S. Bovine casein haplotypes: number, frequencies and applicability as genetic markers. Anim Genet 1993;24(5):373-6.
Machlin L. Effect of growth hormone on milk production and feed utilization in dairy cows. J Dairy Sci 1973; 56(5):575-80.

Maga EA, Cullor JS, Smith W, Anderson GB, Murray JD. Human lysozyme expressed in the mammary gland of transgenic dairy goats can inhibit the growth of bacteria that cause mastitis and the cold-spoilage of milk. Foodborne Pathog Dis 2006; 3(4):384-92.

Mitra A, Schlee P, Krause I, Blusch J, Werner T, Balakrishnan C, Pirchner F. Kappa-casein polymorphisms in Indian dairy cattle and buffalo: A new genetic variant in buffalo. Anim Biotechnol 1998; 9(2):81-7.

Moody D, Pomp D, Barendse W. Rapid communication: restriction fragment length polymorphism in amplification products of the bovine growth hormone-releasing hormone gene. J Anim Sci 1995; 73(12):3789.

Naserian AA, Saremi B. Water buffalo industry in Iran. Ital J Anim Sci. 2007; 6(sup2):1404-5.

Nasr M, Awad A, El Araby I. Associations of Leptin and Pituitary-Specific Transcription Factor Genes' Polymorphisms with Reproduction and Production Traits in Dairy Buffalo. Reprod Domest Anim 2016; 51(4):597-603.

Othman OE, Zayed FA, El Gawead AA, El-Rahman MR. Genetic polymorphism of three genes associated with milk trait in Egyptian buffalo. J Genet Eng Biotechnol 2011; 9(2):97-102.

Parikh RC, Rank DN. Characterization and association of the Pit-1 gene in the Indian buffalo. Indian J Anim Sci 2013; 83(12).

Pasandideh M, Mohammadabadi M, Esmailizadeh A, Tarang A. Association of bovine PPARGC1A and OPN genes with milk production and composition in Holstein cattle. Czech J Anim Sci 2015; 60(3):97-104.

Ranjbar M, Brujeni G, Mashhadi A, Dabbaghyan M. Study of BuLA-DRB3 polymorphism in Khuzestan river buffaloes. J Vet Res 2016; 71(1):Pe33-Pe40.

Riaz MN, Zahur AB, Abbas N, Yousaf M, Shah A, Ishaq R, Suleman M. K-CN gene polymorphism in Nili-ravi buffalo, Achai and Sahiwal cattle of Pakistan. Int J Dairy Technol. 2015;68(1):105-10.

Shakerian M, Kiani H, Ehsani M-R. Effect of buffalo milk on the yield and composition of buffalo feta cheese at various processing parameters. Food Biosci 2016;15:110-7.

Shi DS, Wang J, Yang Y, Lu FH, Li XP, Liu QY. DGAT1, GH, GHR, PRL and PRLR polymorphism in water buffalo (Bubalus bubalis). Reprod domest anim 2012; 47(2):328-34.

Shokrollahi B, Amirinia C, Djadid ND, Amirmozaffari N, Kamali MA. Development of polymorphic microsatellite loci for Iranian river buffalo (Bubalus bubalis). Afr J Biotechnol 2009; 8(24).

Smitz N, Van Hooft P, Heller R, Cornélis D, Chardonnet P, Kraus R, Greyling B, Crooijmans R, Groenen M, Michaux J. Genomewide single nucleotide polymorphism (SNP) identification and characterization in a non-model organism, the African buffalo (Syncerus caffer), using next generation sequencing. Mamm Biol 2016; 81(6):595-603. 
Taghizadeh K, Nasiri MB, Fayazi J, Bujarpoor M. Investigation of (Stearoyl-CoA Desaturase 1) SCD1 Gene Polymorphism in Khuzestan Buffalo Population Using PCR-RFLP Method. Iranian Journal of Applied Animal Science 2014; 4(2):425-8.

Viitala S, Szyda J, Blott S, Schulman N, Lidauer M, Mäki-Tanila A, Georges M, Vilkki J. The role of the bovine growth hormone receptor and prolactin receptor genes in milk, fat and protein production in Finnish Ayrshire dairy cattle. Genetics 2006; 173(4):2151-64.

Watanabe M, Naito M, Sasaki E, Sakurai M, Kuwana T, Oishi T. Liposome-mediated DNA transfer into chicken primordial germ cells in vivo. Mol Reprod Dev 1994; 38(3):268-74.
Woollard J, Schmitz C, Freeman A, Tuggle C. Rapid communication: HinfI polymorphism at the bovine Pit-1 locus. J Anim Sci 1994; 72:3267.

Yao J, Aggrey SE, Zadworny D, Hayes JF, Kühnlein U. Sequence variations in the bovine growth hormone gene characterized by single-strand conformation polymorphism (SSCP) analysis and their association with milk production traits in Holsteins. Genetics 1996; 144(4):1809-16.

Yeh F, Yang R, Boyle T. POPGENE: A Microsoft Windows based freeware for population genetic analysis. Version 1.31, University of Alberta. Center for International Forestry Research, Alberta, Canada. 1999. 